\title{
Exposome: priorities of Ukraine
}

\section{Yu.V. Voronenko, O.P. Hulchiy, N.M. Zakharova, K.V. Balashov, S.M. Turianytsia}

Shupyk National Healthcare University of Ukraine, Kyiv, Ukraine

\begin{abstract}
Objective: to provide proposals of the most important research spheres in human exposome in Ukraine and the resources needed for implementation. Materials and methods. The article contains a literary review of exposome studies since 2012 and comparative analysis of the burden of diseases and their dynamics in Ukraine since 1990 till 2017. Results. In February 2020 the European Network on Human Exposure brought together 126 research centers from 24 European countries and identified 9 global areas of activity. In Ukraine, the most common causes of death due to noncommunicable diseases among people aged 15-49 are coronary heart disease, stroke, cirrhosis, and chronic liver disease, alcohol abuse, and drug use. Conclusion. The participation of Ukrainian specialists and institutions in exposome studies will make a significant contribution to reducing noncommunicable diseases and improving the health of Ukrainians, strengthening the human and scientific potential of higher education and research institutions, providing a strong international partnership for further development of research \& practical cooperation with European countries.
\end{abstract}

Key words: non-communicable diseases, environmental medicine, public health, big data, medical education.

\section{Introduction}

Modern advances in medical science and information technologies enable moving to a higher level in a comprehensive understanding of the problems associated with health and formation of human diseases. One such approach, that humanity heard about for the first time in the last decade and which has only been developed over the last few years by the leading research centers in North America and Western Europe, is exposome analysis. Exposome is a set of influences that a person experiences during his/her life, and their impact on health [1]. This concept is intended to give a more holistic view of the impact of environmental factors in epidemiological studies, and the term «environmental factors» refers to all non-genetic effects on the human body [2].

Objective: to provide proposals of the most important research spheres in human exposome in Ukraine and the resources needed for implementation.

\section{Materials and methods}

The article contains a literary review of exposome studies since 2012: the main concepts and theories of the human exposome were analyzed. On the other hand, the authors provide a comparative analysis of the burden of diseases and their dynamics in Ukraine since 1990 till 2017 , based on data from global databases and World Health Organization (WHO) guidelines [3-6]. Morbidity and mortality rates, changes in the comparative rating (according to the DALY indicator) of the twelve most common non-communicable diseases (NCDs) were analyzed.

\section{Results}

According to the today classic division suggested by S.P. Wild (2012) [2], three domains are distinguished in the exposome:

- internal (properties of a particular organism, such as age, physiology and body morphology, genome, etc.);

- specific external (such as diet, industrial and environmental influences, as well as physical, biological and physiological influences, including smoking, alcohol consumption or medical interventions, etc.);

- general external (housing location, level of education, socioeconomic status, psychological and mental stress, etc.).

Currently, the main tools of information collecting for the exposome construction (Table 1) are identifying biomarkers, using physiological data sensors, geolocation systems and traditional research tools: questionnaires, instrumental and laboratory survey methods, etc. [1].

An important advantage of the exposome-oriented approach is the ability to combine information from different sources and involve methods of working with «big data» to identify and better understand new non-obvious connections and cause-and-effect chains. The study of the simultaneous action of many factors is extremely important, as research shows that environmental influences make a significantly greater contribution to the formation of diseases than individual genetic factors (Table 2) $[7,8]$.
In addition to the theoretical value of the exposome as a methodology for comprehensive study of health effects, its research can be useful for clinical medicine and public health through the introduction of personalized medicine practices, improvement of chemical impact assessment in regions, etc. [1].

In recent years, several research projects have been created to study the individual components of the human exposome:

- the Exposomics project, founded in 2012 at Imperial College London,

studied the impact of using smartphones and environmental sensors;

Table 1 Examples of Approaches and Tools Used for Exposome Evaluation [2]

\begin{tabular}{ll}
\hline \multicolumn{1}{c}{ Approach } & \multicolumn{1}{c}{ Tools } \\
\hline $\begin{array}{l}\text { Biomarkers (omics) } \\
\text { General }\end{array}$ & $\begin{array}{l}\text { Genomics, transcriptomics, proteomics, metabolomics, } \\
\text { epigenomics } \\
\text { Adductomics, lipidomics, immunomics }\end{array}$ \\
$\begin{array}{ll}\text { Targeted } & \text { Environmental pollutants, physical activity, stress, circadian } \\
\text { rhythms, location (global positioning systems — GPS) }\end{array}$ \\
\hline $\begin{array}{l}\text { Sensor technologies (including mobile } \\
\text { phones) }\end{array}$ & Diet, environment, social interactions \\
\hline $\begin{array}{l}\text { Imaging (including mobile phones, } \\
\text { video cameras) }\end{array}$ & $\begin{array}{l}\text { Behaviour and experiences (ecological momentary } \\
\text { assessment), stress, diet, physical activity }\end{array}$ \\
\hline $\begin{array}{l}\text { Portable computerized devices } \\
\text { (including palmtop computers) }\end{array}$ & Job-exposure matrices, dietary recall (e.g. EPIC-Soft) \\
\hline $\begin{array}{l}\text { Improved conventional measurements } \\
\text { (combined with environmental measures) }\end{array}$ & \\
\hline
\end{tabular}

Table 2 Factors Affecting the Body that May be Included in Exposome Research [8]

\begin{tabular}{|c|c|}
\hline Group of influence & Influence \\
\hline \multicolumn{2}{|l|}{ External } \\
\hline Meteorological & Climate change, temperature, humidity, wind, atmospheric pressure \\
\hline Environment & $\begin{array}{l}\mathrm{NO}_{2^{\prime}} \mathrm{SO}_{2^{\prime}} \mathrm{CO}, \mathrm{O}_{3^{\prime}} \text { volatile organic compounds, solid particles, radiation, } \\
\text { ultraviolet, traffic, pollen }\end{array}$ \\
\hline Built environment & $\begin{array}{l}\text { Population density, building density, buildings, green space, passability, security } \\
\text { of the neighborhood, availability of resources (eg hospitals, bus stations), noise }\end{array}$ \\
\hline Home environment & $\begin{array}{l}\text { Volatile organic compounds, solids, } \mathrm{NO}_{2^{\prime}} \mathrm{C} \text {, aldehydes, metals, plasticizers, dust, } \\
\text { pets, allergens (eg house dust mites), mold, fungi, microbes, endotoxins }\end{array}$ \\
\hline Personal behaviour & Diet, exercise, tobacco smoke, alcohol, drugs, sleep, sex, cosmetics \\
\hline Socio-economic & Social factors, education, economics, psychological and mental stress \\
\hline $\begin{array}{l}\text { Food and water pollu- } \\
\text { tion }\end{array}$ & $\begin{array}{l}\text { Fertilizers, metals, pesticides, plasticizers, disinfectants, biphenyl } \\
\text { polychloride, flame retardants, per- and polyfluoroalkyl substances }\end{array}$ \\
\hline Medication & Medicines, surgical intervention \\
\hline Professional influences & Chemicals, dust, metals, viruses, animal proteins, plants, heat/cold exposure \\
\hline \multicolumn{2}{|l|}{ Internal } \\
\hline & $\begin{array}{l}\text { Primary external radiation and related metabolites, epigenetic (eg, } \\
\text { methylation, histone modifications), changes in microbiome/ } \\
\text { metabolome/proteome/transcriptome/genome, etc. }\end{array}$ \\
\hline
\end{tabular}


- in 2013, the European project HEALS was launched, which investigated the links between DNA sequence, epigenetic changes in DNA, gene expression and environmental factors;

- the HELIX project (Barcelona, Spain), founded in 2014 and based at the Center for Research in the Field of Environmental Epidemiology, aimed at studying the exposomes of young children;

- the concept of exposome is developed in US projects:

- Human Exposome Project (HEP), humanexposomeproject. com;

- National Institute of Occupational Safety and Health (NIOSH), cdc.gov/niosh/topics/exposome/default.html;

- National Institute of Environmental Health Sciences (NIEHS), niehs.nih.gov/news/events/pastmtg/2018/exposome/index.cfm;

- the University of British Columbia (Canada), socialexposome. ubc.ca.

Perhaps the most important event in this innovative scientific field was the establishment in February 2020 of the European Network on Human Exposure (humanexposome.eu). The project brought together 126 research centers from 24 European countries, attracted 106 million euros from the European Commission and identified nine global areas of activity, each of which is a separate research project and includes from 11 to 22 partner institutions:

- ATHLETE (Advancing Tools for Human Early Life Course Exposome Research and Translation) - Tools to improve research and transfer information about the early stages of human life;

- EPHOR (Exposome Project for Health and Occupational Research) - Exposome project for health and occupational research;

- EQUAL-LIFE (Early Environmental Quality and Life-Course Mental Health Effects) - The quality of the environment at a young age and the consequences for mental health throughout life;

- EXIMIOUS (Mapping Exposure-Induced Immune Effects: Connecting the Exposome and the Immunome) - Mapping exposure-induced immune effects: the relationship between the exposome and the immune;

- EXPANSE (Exposome Powered Tools for Healthy Living in Urban Settings) - Exposome tools for healthy living in urban conditions;

- HEAP (Human Exposome Assessment Platform) - Platform for Human Exposure Assessment;

- HEDIMED (Human Exposomic Determinants of Immune Mediated Diseases) - Determinants of the human exposome in immune-mediated diseases;

- LONGITOOLS (Dynamic Longitudinal Exposome Trajectories in Cardiovascular and Metabolic Non-Communicable Diseases) - Dynamic long-term models/pathways of exposomes in cardiovascular and metabolic non-infectious diseases;

- REMEDIA (Impact of Exposome on the Course of Lung Diseases) - The contribution of the exposome in the development of lung diseases.

Given the ongoing reform of the health care system that is underway in Ukraine, the orientation and direct participation in the development of the world's leading scientific and practical medical innovations will allow us to achieve high standards of public health while avoiding possible mistakes and saving resources.

To determine the scope of prior attention for Ukraine within the study of the exposome, it is necessary to analyze the burden of diseases and their dynamics over the past decades.

About $40 \%$ of cases in the mortality structure among people aged 15-49 years and $80 \%$ of 50-69-year-olds worldwide are NCDs, traditionally used to denote four main groups of pathologies: diseases of the cardiovascular and respiratory systems, malignant neoplasms and diabetes mellitus) [9]. In Ukraine, this figure is approximately $60 \%$ and $90 \%$, respectively.

The most common causes of death due to NCDs among people aged 15-49 are:

- coronary heart disease $(8.5 \%$ in the structure of mortality in the world and $10.2 \%$ in Ukraine);

- stroke (4.8\% and $4.4 \%$, respectively);

- cardiomyopathy and myocarditis (0.9\% and $7.0 \%$, respectively);
- cirrhosis and chronic liver disease (4.4\% and 9.9\%, respectively); alcohol abuse (1.1\% and 5.2\%, respectively) and drug use (1.3\% and $1.5 \%$, respectively);

- breast cancer (1.6\% and $1.3 \%$, respectively), respiratory cancer ( $1.4 \%$ and $1.3 \%$, respectively), other cancers (up to $14 \%$ and up to $12 \%$, respectively);

- chronic obstructive pulmonary disease (approximately $2 \%$ and $0.6 \%$, respectively);

- diabetes mellitus ( $1.5 \%$ and $0.5 \%$, respectively).

Changes in the comparative rating (according to the DALY indicator) of the twelve most common NCDs in Ukraine and the world (Fig. 1) are insignificant and show internal regrouping without the appearance of new groups of diseases in the ranking. In Ukraine (2015) the mortality rate of people of working age due to NCDs (617 per 100 thousand population) is one and a half times higher than the average for the WHO European Region (380 per 100 thousand), and more than three times - for the Scandinavian countries (186 per 100 thousand). Since 1985, the highest mortality rate from these diseases was registered in 1994 (906 per 100 thousand), and from 2005 (867 per 100 thousand) to 2015 shows a steady decrease.

Analysis of the dynamics of the prevalence of 4 groups of NCDs since 1990 shows a significant increase in the prevalence of diseases of the circulatory system, diabetes mellitus, cancer and chronic obstructive pulmonary disease, with a tendency for stabilizing after 2013 (Fig. 2).

\section{Discussion}

Based on the analysis of the structure and dynamics of morbidity in Ukraine, the priority areas for the state research of the human exposome are:

1. Study of the influence of environmental factors on the development of NCDs, in particular cardiovascular, metabolic diseases, chronic gastrointestinal pathology.

2. Assessment of impacts at an early stage of human life in order to predict and prevent the development of diseases.

3. Assessment of the impact of environmental factors on the formation of risky behavior (high level of injuries, alcoholism and drug addiction, etc.), including the impact of military conflicts on human exposome, physical and mental health (for subpopulations: military and their families, temporarily displaced persons, residents of the armed conflict zone, etc.).

4. The role and contribution of radiation pollution to the formation of pathologies, including malignant neoplasms. Challenges of combined influence of factors.

5. Children and new technologies: risks and opportunities in the context of exposome study.

\section{Identification of Resources}

In 2019, the Human Health Exposure Analysis Resource (HHEAR) consortium was established on the basis of the NIEHS (USA), which includes three divisions:

- a network of laboratories that provide collection and analysis of impacts, both hypothesis-oriented and data-oriented approach;

- a data center that stores, maintains, analyzes, interprets, and integrates data generated by the HHEAR network.

- the Coordination Center, which manages projects and coordinates them, communicates with the consortium members.

For the effective operation of the network of research centers for the study of exposomes it is necessary:

- to determine the coordinator and regional coordinators of the project (research \& practical centers);

- to identify primary information facilities (health facilities, public health centers, laboratory centers, etc.);

- to determine the target parameters, the indicators of which will be monitored;

- to determine the required amount of additional funding, the amount of activities that do not require additional funding, sources of funding; 
Global

1990 rank

Both sexes, 15-49 years, DALYs per 100,000

\begin{tabular}{|c|c|}
\hline 1 Cardiovascular diseases & 1 Mental disorders \\
\hline 2 Mental disorders & 2 Musculoskeletal disorders \\
\hline 3 Musculoskeletal disorders & 3 Cardiovascular diseases \\
\hline 4 Neoplasms & 4 Neoplasms \\
\hline 5 Neurological disorders & 5 Neurological disorders \\
\hline 6 Digestive diseases & 6 Other non-communicable \\
\hline 7 Other non-communicable & 7 Substance use \\
\hline 8 5ubstance use & 8 Digestive diseases \\
\hline 9 Chronic respiratory & 9 Diabetes \& CKD \\
\hline 10 Diabetes \& CKD & 10 Chronic respiratory \\
\hline 11 Skin diseases & 11 Sense organ diseases \\
\hline 12 Sense organ diseases & 12 Skin diseases \\
\hline
\end{tabular}

Ukraine

1990 rank Both sexes, 15-49 years, DALYs per 100,000

\begin{tabular}{|c|c|}
\hline 1 Cardiovascular diseases & 1 Cardiovascular diseases \\
\hline 2 Neoplasms & 2 Digestive diseases \\
\hline 3 Mental disorders & 3 Neoplasms \\
\hline 4 Musculoskeletal disorders & 4 Substance use \\
\hline 5 Substance use & 5 Musculoskeletal disorders \\
\hline 6 Neurological disorders & 6 Mental disorders \\
\hline 7 Other non-communicable & 7 Neurological disorders \\
\hline 8 Digestive diseases & 8 Other non-communicable \\
\hline 9 Chronic respiratory & 9 Diabetes \& CKD \\
\hline 10 Diabetes \& CKD & 10 Sense organ diseases \\
\hline 11 Skin diseases & 11 Chronic respiratory \\
\hline 12 Sense organ diseases & 12 Skin diseases \\
\hline
\end{tabular}

Figure 2 Dynamics of the prevalence of NCDs since 1990 [10]

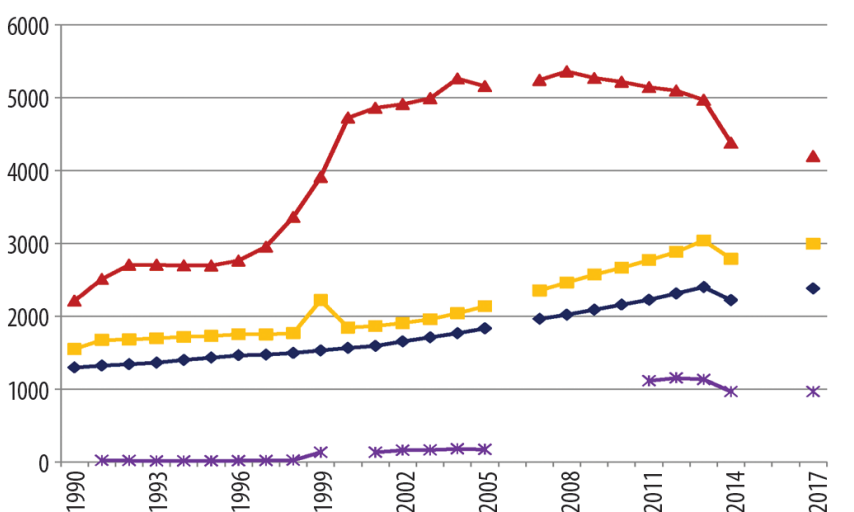

- Cancer prevalence per 100,000 of population

- Diabetes mellitus prevalence per 100,000 of population

-Diseases of the circulatory system incidence (in outpatients) per 100,000 of population

*- Chronic obstructive pulmonary disease prevalence per 100,000 of population

- to define the system of information exchange at the organizational (frequency and form of reporting) and technical (data storage, protection, information channels) levels;

- to ensure that the professional community and society in general are informed about the implementation of the project in order to form a positive image of the project and commitment to it in different groups of stakeholders.

\section{Determination of Human Resources}

According to A.K. Manrai et al. (2017) [11], the main challenge in human exposomal research is, first and foremost, the integration of «big data» covering statistics, computer science, biomedicine and public health. This requires the training of a new generation of researchers who will be able to bridge the gap between individual research areas and work effectively in multidisciplinary research consortia or teams.

In Ukraine, such multidisciplinary teams may consist of public health professionals (population component), clinicians in the rele- vant specialty (personal component), professionals in statistical processing and technical means of reading health information, geneticists, biochemists, etc. Regional research centers in Ukraine can be formed on the basis of relevant institutions of higher medical education, which will ensure the organization of information collection, its primary processing, and form regional priorities, and so on.

As human exposomes have been studied for a long time in nonlaboratory settings, it is necessary to train field staff to be ready to participate in this type of research. A package of a series of certificate training courses and a series of master classes are being developed at the Shupyk National Healthcare University of Ukraine aimed at preparing medical doctors to perform tasks targeted at assessing the human exposome.

\section{Research Opportunities}

The study of human exposomes opens a wide field for scientific research, both in medical and non-medical settings, as it involves the collection and study of data on the functioning of the human body over time.

The priority areas here are:

1. The study of changes that occur at the subcellular level in response to various types of external and internal influences.

2. Detection of early markers of disease development.

3. Construction of models that will allow to extrapolate the results of exposomal studies to the rest of the population, etc., prevent the development of diseases.

4. Development of proposals for a personalized approach to the treatment of patients, taking into account the data of real or simulated patient exposomes.

5. Study of the influence of intangible (social, psychological, etc.) factors on human exposome.

6. Development and improvement of methods of analysis and visualization of «big data» in the field of health care.

7. Development of innovative software and equipment for human exposome research.

The first step of our country in the study of human exposomes can be a project that focuses on the study of autoimmune diseas- 
es (rheumatoid arthritis, autoimmune thyroiditis Hashimoto, etc.). The Shupyk National Healthcare University of Ukraine and Kyiv City Clinical Endocrinology Center are participating in the preparation of a tender for the Marie Skłodowska - Curie program in the field of «Innovative Training Networks».

The project, developed on the principles of translational medicine, provides a combination of research, educational and clinical components and is designed to provide:

- training of modern specialists who have acquired methods of epigenetic and epidemiological research and have experience working in multidisciplinary teams, possess knowledge and skills for effective research \& practical activities in the field of health care, including on career development;

- standardization and testing of epigenetic (such as telomere measurements or histone acetylation) and genetic (polygenetic risk determination) variables for further research in reproductive health and autoimmune diseases with unequal gender distribution;

- identification of measurable specific disease markers.

The consortium included 26 partners from 16 countries. The project is designed for three years and provides for the annual holding of summer schools to intensify scientific and practical exchange and continuous professional development of project participants.

\section{Conclusions}

The human exposome is the latest concept in health care, based on modern means of obtaining information, the ability to analyze «big data», the human genome and proteome. In 2020, 126 research centers from 24 European countries joined to form the European Human Exposure Network (humanexposome.eu), which attracted significant grant funding from the European Commission.

The participation of national specialists and institutions in these studies will make a significant contribution to reducing NCDs and improving health of Ukrainians, strengthening the human and scientific potential of higher education and research institutions of our country, providing a strong international partnership for further development of research \& practical cooperation with European countries, WHO region.

Conflict of interests: the authors declare no conflict of interests.

\section{References:}

1. DeBord D.G., Carreón T., LentzTh.J. (2016) Use of the «Exposome» in the Practice of Epidemiology: A Primer on — Omic Technologies. Am. J. Epidemiol., 302-314. doi: 10.1093/aje/kwv325

2. Wild C.P. (2012) The exposome: from concept to utility. Int. J. Epidemiol., 24-32. D0l: 10.1093/ ije/dyr236

3. World Health Organization (2013) Global action plan for the prevention and control of noncommunicable diseases 2013-2020 (https://www.who.int/publications/i/ item/9789241506236).
4. World Health Organization (2018) Noncommunicable diseases country profiles 2018 (https:// www.who.int/nmh/publications/ncd-profiles-2018/en/).

5. World Health Organization (2016) Global difusion of eHealth: making universal health coverage achievable (https://apps.who.int/iris/bitstream/handle/10665/252529/9789241511780eng.pdf?sequence $=1$ ).

6. World Health Organization (2018) Global action plan on physical activity 2018-2030: more active people for a healthier world (https://apps.who.int/iris/bitstream/hand le/10665/272722/9789241514187-eng.pdf).

7. Rappaport S.M. (2010) Implications of the exposome for exposure science. J. Expo Sci. Environ. Epidemiol., 21(1): 5-9. Dol: 10.1038/jes.2010.50

8. Zhang P., Arora M., Chaleckis R. et al. (2019) Tackling the Complexity of the Exposome: Considerations from the Gunma University Initiative for Advanced Research (GIAR) Exposome Symposium. Metabolites, 9(6): 106. doi: 10.3390/metabo9060106

9. https://vizhub.healthdata.org/gbd-compare/

10. State Center of The Medical Statistics of Ukraine (2020) Health for All. Ukraine. (Database).

11. Manrai A.K., Cui Yu., Bushel P.R. et al. (2017) Informatics and Data Analytics to Support Exposome-Based Discovery for Public Health. Ann. Rev. Public Health, 20(38): 279-294. DOl: 10.1146/annurev-publhealth-082516-012737

\section{Експосома: пріоритети для України}

Ю.В. Вороненко, О.П. Гульчій, Н.М. Захарова, К.В. Балашов,

\section{С.М. Туряниця}

Національний університет охорони здоров'я

України імені П.Л. Шупика, Київ, Україна

Анотація. Мета: розроблення пропозицій щодо перспективних напрямів дослідження експосоми людини в Україні та визначення необхідних ресурсів для їх реалізації. Об'єкт і методи дослідження. Стаття містить огляд літератури щодо досліджень експосоми людини з 2012 р. та порівняльний аналіз тягаря захворювань та їх динаміки в Україні в період 1990-2017 рр. Peзультати. У лютому 2020 р. European Network on Human Exposure об'єднала 126 дослідних центрів із 24 країн Європи і визначила 9 глобальних сфер діяльності. В Україні найпоширенішими причинами смерті серед людей віком 15-49 років $\epsilon$ неінфекційні захворювання: ішемічна хвороба серця, інсульт, цироз та хронічні захворювання печінки, зловживання алкоголем та вживання наркотиків. Висновок. Участь українських спеціалістів та установ у дослідженнях експосоми зробить вагомий внесок у зниження неінфекційної захворюваності та в покращення здоров'я українців, зміцнення людського і наукового потенціалу вищих навчальних закладів та науково-дослідних установ, забезпечення міцного міжнародного партнерства для подальшого розвитку науково-практичного співробітництва з європейськими країнами.

Ключові слова: неінфекційні захворювання, екологічне здоров'я, громадське здоров'я, великі дані, медична освіта.

\section{Відомості про авторів:}

Вороненко Юрій Васильович — доктор медичних наук, професор, академік Національної академії медичних наук України, ректор Національного університету охорони здоров'я України імені П.Л. Шупика, Київ, Україна. ORCID ID: 0000-0002-4852-3324

Гульчій Олеся Петрівна — доктор медичних наук, професор, проректор з міжнародних зв'язків та науково-педагогічної роботи з іноземними громадянами Національного університету охорони здоров'я України імені П.Л. Шупика, Київ, Україна. ORCID ID: 0000-0001-8283-8672

Захарова Надія Миколаївна — кандидат медичних наук, доцент кафедри громадського здоров'я Національного університету охорони здоров'я України імені П.Л. Шупика, Київ, Україна. ORCID ID: 0000-0002-6530-6217

Балашов Костянтин B'ячеславович — завідувач відділу комунікацій Національного універси тету охорони здоров'я України імені П.Л. Шупика, Київ, Україна. ORCID ID: 0000-0002-7820-4527 Туряниця Соломія Михайлівна - магістр екології, асистент кафедри громадського здоров'я Національного університету охорони здоров'я України імені П.Л. Шупика, Київ, Україна. ORCID ID: 0000-0002-4294-198X

\section{Адреса для кореспонденції:}

Балашов Костянтин В'ячеславович

04112, Київ, вул. Дорогожицька, 9

E-mail:kostyantyn.balashov@gmail.com

\section{Information about the authors:}

Yuriy V. Voronenko - Doctor of Medical Sciences, Professor, Academician of the National Academy of Medical Sciences of Ukraine, Rector of the Shupyk National Healthcare University of Ukraine, Kyiv, Ukraine. ORCID ID: 0000-0002-4852-3324

Olesya P. Hulchiy — Doctor of Medical Sciences, Professor, Vice-Rector for International Relations and International Students Research \& Training of the Shupyk National Healthcare University of Ukraine, Kyiv, Ukraine. ORCID ID: 0000-0001-8283-8672

Nadiia M. Zakharova - Associate Professor, Head of the Department of Master's Degree Programmes of the Shupyk National Healthcare University of Ukraine, Kyiv, Ukraine. ORCID ID: 0000-0002-6530-6217

Kostyantyn V. Balashov - Head of the Department of Communications of the Shupyk National Healthcare University of Ukraine, Kyiv, Ukraine. ORCID ID: 0000-0002-7820-4527

Solomiya M. Turianytsia - Assistant Professor of the Department of Public Health of the Shupyk National Healthcare University of Ukraine, Kyiv, Ukraine. ORCID ID: 0000-00024294-198X

Address for correspondence:

Kostyantyn Balashov

04112, Kyiv, Dorohozhytska str., 9

E-mail: kostyantyn.balashov@gmail.com 